\title{
Tissue-Specific Expression of a Drosophila Calcium-Activated Potassium Channel
}

\author{
Marie N. Becker, ${ }^{a}$ Robert Brenner, and Nigel S. Atkinson \\ Department of Zoology, The University of Texas at Austin, Austin, Texas 78712-1064
}

\begin{abstract}
The Drosophila slowpoke (s/o) gene encodes a subunit of a CAK channel homologous to the vertebrate BK channel. We have examined slo expression throughout development. It is expressed in muscle cells, neurons of the CNS and PNS, mushroom bodies, a limited number of cells in embryonic and larval midgut and in epithelial-derived tracheal cells. The promoter has been cloned and shown to direct expression in the same pattern as the endogenous gene in both neural and epithelial-derived cells. During pupariation and embryogenesis, slo is expressed in muscles many hours prior to the appearance of functional channels.

[Key words: $\mathrm{Ca}^{2+}$-activated $\mathrm{K}^{+}$channel, Drosophila, slowpoke, development, gene expression, reporter gene, antibody]
\end{abstract}

A cell's electrical properties are determined by the complement of ion channels expressed. In Drosophila, the small size of neurons and the absence of identified neuronal circuits have impeded the characterization of neuronal channels. Electrophysiological studies are largely restricted to a number of large accessible muscle fibers. Drosophila muscle has four well-characterized $\mathrm{K}^{+}$ currents, $I_{\mathrm{A}}, I_{\mathrm{K}}, I_{\mathrm{CS}}, I_{\mathrm{CF}}$, and one inward voltage-activated $\mathrm{Ca}^{2+}$ current, $I_{\mathrm{Ca}} \cdot I_{\mathrm{A}}$ and $I_{\mathrm{K}}$ are voltage-activated $\mathrm{K}^{+}$(VAK) currents while $I_{\mathrm{CS}}$ and $I_{\mathrm{CF}}$ are $\mathrm{Ca}^{2+}$-activated $\mathrm{K}^{+}(\mathrm{CAK})$ currents. During embryonic muscle development, $I_{\mathrm{CA}_{\mathrm{A}}}, I_{\mathrm{K}}$, and $I_{\mathrm{A}}$ appear about $13.25 \mathrm{hr}$ after laying of the embryo (Broadie and Bate, 1993). The appearance of $I_{C S}$ and $I_{\mathrm{Cr}}$ occurs $4 \mathrm{hr}$ later, just prior to the hatching of the larvae, when embryogenesis is essentially complete. During the $4 \mathrm{~d}$ of pupariation, muscle currents appear in the order $I_{\mathrm{CS}}, I_{\mathrm{A}}, I_{\mathrm{K}}, I_{\mathrm{Ca}}$ followed by $I_{\mathrm{CF}}$ which appears during about $1 \mathrm{~d}$ after the adult leaves the pupal case (Salkoff, 1985; Wei and Salkoff, 1986). We are interested in how cells regulate the expression of genes responsible for these currents.

We have assayed the tissue- and developmental-specific expression of the Drosophila CAK channel gene called slowpoke $\left(\right.$ slo). The slo gene encodes the channel that conducts $I_{\mathrm{CH}}$ and was the first CAK channel gene to be identified. This gene was identified as a behavioral mutant (called $s l o^{1}$ ) (Elkins et al.,

Received Mar. 14, 1995; revised May 16, 1995; accepted May 19, 1995.

M.N.B. and R.B. contributed equally to this work. We thank Janet Young and Gwen Gage for their help with the figures, Kathleen Mosely for assistance with the plastic sections, Susan Gustavson for advice concerning the cryostat sections, Jessica Moore for consultations concerning fly transformations, and Harold Zakon for proofreading the manuscript. This work was supported by NSF Grant IBN-9212405 to N.S.A. M.B. and R.B. were supported in part by NIH Training Grant 5T-32HD07296-02GT.

Correspondence should be addressed to Nigel Atkinson at the above address.

"Present address: Southwestern University, Biology Department., Creorgetown, TX.

Copyright (C) 1995 Society for Neuroscience $0270-6474 / 95 / 156250-10 \$ 05.00 / 0$
1986). This mutation causes abnormal behavior following strong sensory stimuli $\left(37^{\circ} \mathrm{C}\right.$ heat pulse or a cool but bright light). Genetic and physiological analysis indicated that the mutation specifically eliminated $I_{\mathrm{Cr}}$ in muscles and neurons (Salkoff, 1983; Elkins et al., 1986; Gho and Mallart, 1986; Singh and Wu, 1989; Komatsu et al., 1990; Broadie and Bate, 1993). The channel's current has been characterized in embryonic and larval body wall muscles, larval motoneurons and indirect flight muscles. In flight muscle its primary function is action potential repolarization (Elkins et al., 1986). It has also been proposed that $I_{\mathrm{CH}}$ participates in motoneuron nerve terminal repolarization (Gho and Mallart, 1986). It is not known, however, whether slo expression is restricted to particular cell types or if it is widely expressed in excitable cells.

The gene was cloned in a chromosomal walk initiated from an inversion breakpoint (Atkinson et al., 1991). Sequence analysis suggested that the structure of CAK channels were similar to that of VAK channels. Strong amino acid similarity was limited to the putative voltage sensor (S4) and the H5 domain which composes a large portion of the pore (Atkinson et al., 1991). Furthermore, expression of RNA produced from the cloned gene causes the production of $\mathrm{Ca}^{2+}$-activated $\mathrm{K}^{+}$channels in Xenopus oocytes (Adelman et al., 1992). The slo channel is structurally and functionally homologous to the vertebrate BK-type CAK channel (Butler et al., 1993; Knaus et al., 1994).

We have determined the developmental and tissue-specific expression of $s l o$. We have shown that slo is broadly expressed in neurons and muscles and that muscle expression precedes the developmental appearance of the current by many hours. Expression also occurs in tracheal cells and some cells in the larval midgut.

\section{Materials and Methods}

Stocks. Drosophila stocks used were Canton $S$ (wild type), slo (null mutation in slo gene) and $w^{1118}$. Stocks were maintained using standard Drosophila hushandry techniques.

Transformation construct. In order to isolate the slo promoter, embryonic and adult head cDNA libraries were screened for slo cDNA clones containing the most $5^{\prime} \mathrm{mRN} \Lambda$ sequence. This sequence was used as a probe for cosmid genomic clones containing the start of transcription and hence the slo promoter region. An Apal/BamHI DNA fragment cDNA clone Z54 (nucleotide -206 to +207 of translation start; Atkinson et al., 1991) was used to screen $1 \times 10^{6}$ cDNA clones from an embryonic (Hamilton et al., 1991) and $1 \times 10^{\circ} \mathrm{cDNA}$ clones from an adult head (kind gift from Thomas Schwarz, Stanford University School of Medicine) cDNA library. Two classes of cDNAs were isolated containing either of two $5^{\prime}$ exons, $\mathrm{C} 1$ or $\mathrm{C} 2$, spliced to the first common exon C3. RNase protection indicated these $5^{\prime}$ exons are part of mature transcripts (data not shown). Sequencing of $\mathrm{Cl}$ and $\mathrm{C} 2$ containing cDNAs showed that these clones do not contain a common $5^{\prime}$ exon, indicating these clones do not arise from alternative splicing but represent alternative $5^{\prime}$ exons. Cosmid S13 was isolated in a walk into the 


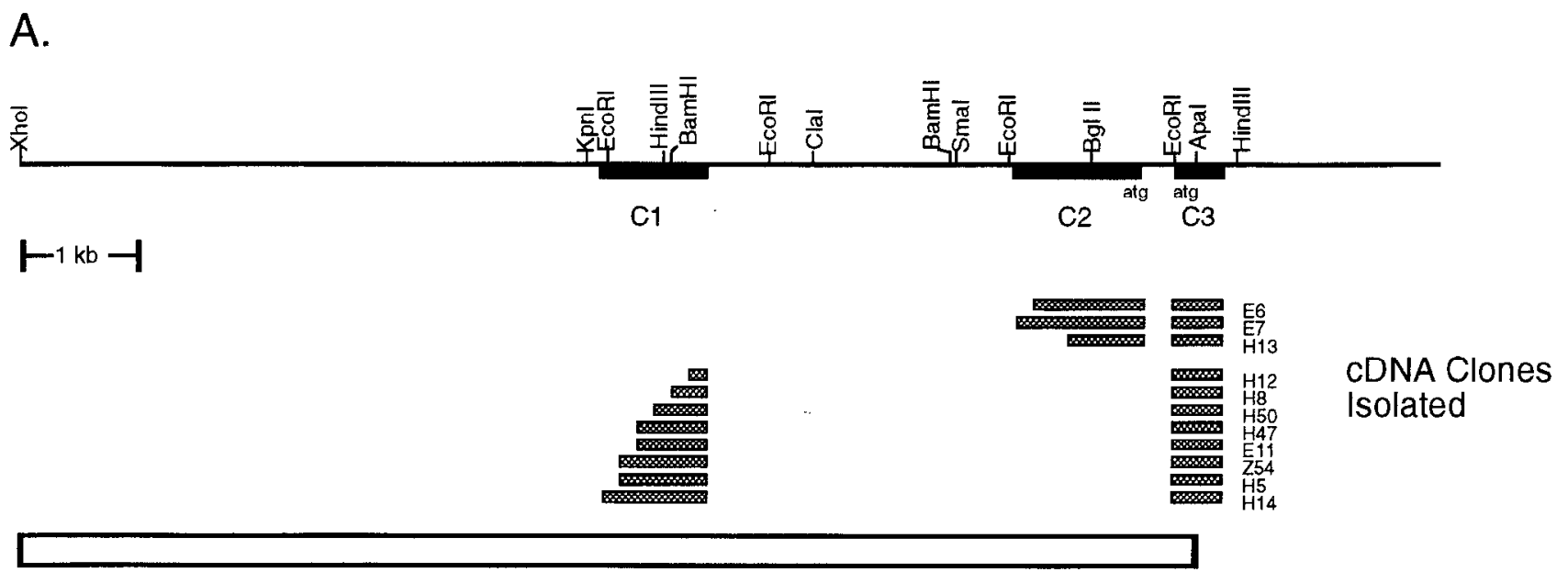

B.

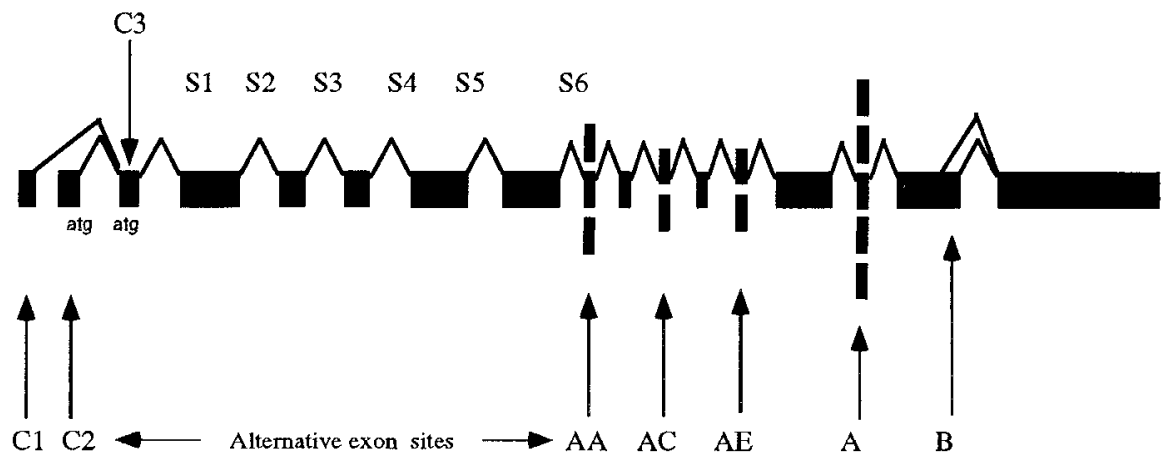

Figure 1. Molecular maps of slo. A, Restriction map of genomic DNA from the $5^{\prime}$ end of the slo gene. Black boxes represent regions encoding the gene's first three exons $(C 1, C 2, C 3)$. Both the $\mathrm{C} 2$ and $\mathrm{C} 3$ exons contain methionine codons that could be used to begin translation. Gray boxes represent cDNAs isolated from embryo (E prefix) and adult head ( $\mathrm{Z}$ and $\mathrm{H}$ prefixes) libraries. DNA sequencing was used to align genomic DNA and cDNAs. The large open box identifies the XhoI-Apal fragment used to construct the P1-9 slo/lacZ reporter gene. B, Splicing map of slo showing the rclative position of alternative exons and the putative transmembrane domains S1-S6 (Atkinson et al., 1991; Adelman et al., 1992; Atkinson, unpublished observations). Antisera Abl673 was raised against a fusion protein made from the 3 '-most exon. In situ hybridizations were performed using probes derived from the same exon.

slo gene (Atkinson et al., 1991). Hybridization and DNA sequence comparison with $5^{\prime}$ slo cDNAs identified this cosmid as containing the furthest $5^{\prime}$ slo exons. A $10 \mathrm{~kb}$ Xhol/Apal fragment of $\mathrm{S} 13$ beginning 5 $\mathrm{kb}$ upstream of exon $\mathrm{Cl}$ and ending 211 nucleotides into common exon C3 was subcloned in translational frame with the lac $Z$ gene of P-element transformation plasmid pCaSperßgal (Thummel et al., 1988) containing a modified polylinker (Fig. 1).

Germline transformation. Germline transformations were as described (Spradling, 1986). The plasmid pp25.7wc (200 ng/ $\mu \mathrm{l})$ and the promoter transformation construct $(1 \mathrm{mg} / \mu \mathrm{l})$ were microinjected into $w^{1118}$ embryos. A single transformant containing an integration in the third chromosome was obtained called P1-9a. This P-element insertion was homozygous lethal in adult flies. Additional insertion sites were obtained by mobilizing P1-9 using the transposase source $\Delta 2-3$ (Robertson et al., 1988). Flies containing different insertion sites were identified based on linkage of the vector encoded white gene to a different or balancer chromosome. Two additional lines were identified, PI-9b and $\mathrm{P} 1-9 \mathrm{c}$ containing integrations in the second chromosome and third balancer chromosome TM6, respectively. Comparison of the lacZ staining pattern in the mobilized and original insertion lines showed no difference in tissue specific staining patterns. In order to make flies containing three copies of the promoter construct, lines were crossed to generate a stock $w^{1118} ; \mathrm{P} 1-9 \mathrm{~b} / \mathrm{CyO} ; \mathrm{Pl}-9 \mathrm{a} / \mathrm{P} 1-9 \mathrm{c}$ TM6. This stock is referred to as P1-9.

Production of polyclonal antisera Abl673. A $1.8 \mathrm{~kb} \mathrm{BglII/EcoRV}$ fragment containing the coding region for the last 310 amino acids of slo cDNA clone Z8 (Atkinson et al., 1991) was subcloned into the BamHI/Smal site of the pGEX-3X glutathione transferase fusion bac- terial expression plasmid (Smith and Johnson, 1988). Bacterial expres sion was as described by Smith and Johnson (1988). Because the majority of fusion protein was in inclusion bodies, the protein was partially purified by repetitive washing of inclusion bodies in PBS (130 Inm $\mathrm{NaCl}, 7 \mathrm{~mm} \mathrm{Na}_{2} \mathrm{HPO}_{4}, 3 \mathrm{~mm} \mathrm{NaH} \mathrm{PO}_{4}$ ) containing $1 \%$ Triton X-100. The inclusion bodies were then solubilized in $8 \mathrm{M}$ urea in PBS. After dialysis to remove the urea, the fusion protein was further purified by electrophoresis through a SDS polyacrylamide gel. A polyacrylamide gel slice containing approximately $200 \mu \mathrm{g}$ of the fusion protein was washed in PBS, emulsified in Freund's complete adjuvant and injected into a New Zealand White rabbit. The initial immunization was followed by immune boosts of 200 ug of fusion protein in Freund's incomplete adjuvant $30,44,58$, and $72 \mathrm{~d}$ after the initial immunization. Immune sera collected $82 \mathrm{~d}$ after initial immunization was preabsorbed to an acetone powder of bacteria expressing glutathione transferase to remove antibodies to glutathione transferase (Sambrook et al., 1989). The preabsorbed immune sera was then affinity purified with the fusion protein (Sambrook et al., 1989) with the following modifications. Approximately $1 \mathrm{mg}$ of fusion protein was affixed to PVDF membranes before binding of serum. Before elution of anti-slo antisera, the membranes were washed with PBS containing $2 \%$ Tween-20 to remove nonspecific antibodies.

Immunohistochemistry. Prior to sectioning, whole flies or dissected heads were fixed for $1-2 \mathrm{hr}$ in $4 \%$ paraformaldehyde on ice followed by an overnight incubation at $4^{\circ} \mathrm{C}$ in $12 \%$ sucrose in PBS. Tissue was embedded in OCT (Miles Scientific) and frozen in liquid nitrogen. 10 $\mu$ sections were cut at $-16^{\circ} \mathrm{C}$ using a I.E.C. cryostat and placed on Fisher SuperFrost slides. Slides were stored desiccated at $-20^{\circ} \mathrm{C}$. 
Processing of slides was essentially as described by Schwarz et al. (1990) with the following exceptions. The antibody dilution buffer did not contain bovine serum albumin (BSA). Ab1673 was used at a dilution of $1 / 50$ or $1 / 25$. Anti $\beta$ galactosidase antibody (monoclonal, Promega) was used at a dilution of $1 / 500$. Slides were incubated at $4^{\circ} \mathrm{C}$ overnight in a humid chamber. The biotinylated goat anti-rabbit secondary antibody (Vector Labs) was used at a dilution of 1/200 and the dilution buffer contained $0.15 \mathrm{M} \mathrm{NaCl}$, no BSA and $2 \%$ goat serum. After incubation with the secondary antibody, slides were washed once for $10 \mathrm{~min}$ in $0.1 \mathrm{M}$ sodium phosphate buffer, $\mathrm{pH} 7.2$ with $0.3 \%$ Triton $\mathrm{X}-100$ and then washed twice more in sodium phosphate buffer $\mathrm{pH} 7.2$ without Triton $\mathrm{X}-100$ for $10 \mathrm{~min}$ each. Remaining steps followed the manufacturer's protocol for the Vectastain ABC kit (Vector Labs) using $0.5 \mathrm{mg} / \mathrm{ml}$ DAB in PBS plus $0.003 \%$ hydrogen peroxide. The color reaction was stopped after $15-30 \mathrm{~min}$ by washing the slides twice in PBS for $10 \mathrm{~min}$. Slides were dehydrated through an ethanol series with a final wash in xylene and mounted in DPX medium (BDH Laboratory Supplies). Photographs were taken using a Zeiss Axioplan microscope. Controls were sections of $s l^{4}$ flies, and sections of $w^{1 / 18}$ flies stained with preimmune sera or with secondary antibody alone.

Prior to antibody staining of larvae, Abl673 (1/25 dilution) and biotinylated goat anti-rabbit antibody (1/100 dilution) were pre-absorbed to dissected $s / o^{4}$ and $w^{1118}$ larvae, respectively. Larvae were cut along the dorsal midline, pinned to a Sylgard dish, and fixed in $1 \%$ glutaraldehyde in PBS for $15 \mathrm{~min}$. Larvae were washed in three $10 \mathrm{~min}$ washes of PBT (PBS with $0.05 \%$ Triton X-100), blocked 1 hr in PBT containing $10 \%$ goat serum, and then incubated overnight with Abl673 in PBT, $10 \%$ goat serum at $4^{\circ} \mathrm{C}$. The larvae were then washed in six $10 \mathrm{~min}$ washes of PBT and incubated with secondary antibody in PDT for $1 \mathrm{hr}$ at room temperature. Following six $10 \mathrm{~min}$ washes of PBT, the antibody was detected using the Vectastain $\mathrm{ABC}$ reagents and manufacturer's protocols (Vector Labs). After staining, the larval body walls with the attached tracheal cells were dissected and mounted on slides in PBS, $80 \%$ glycerol for microscopy.

$\beta$-Galactosidase staining. Embryos were stained for $\beta$-galactosidase activity according to a modification of published procedures (Klambt et al., 1991). Fmbryos were dechorionated in $50 \%$ bleach and then fixed for $30 \mathrm{~min}$ in $5 \mathrm{ml}$ of $5 \%$ paraformaldehyde in PBS and $5 \mathrm{ml}$ of heptane. The fixative and heptane were removed and the embryos were washed in eight changes of PBS, $0.3 \%$ Triton X-100 over 2 hr. Embryos were then stained in $\mathrm{Fe} / \mathrm{Na}$ Phosphate $\mathrm{X}$-gal staining solution containing 10 $\mathrm{mM} \mathrm{NaPO}_{4} \mathrm{pH} 7.2,150 \mathrm{~mm} \mathrm{NaCl}, 1 \mathrm{~mm} \mathrm{MgCl}_{2}, 3 \mathrm{~mm} \mathrm{~K}_{4}\left(\mathrm{FeII}(\mathrm{CN})_{6}\right)$, $3 \mathrm{mM} \mathrm{K}_{3}\left(\mathrm{FeIII}(\mathrm{CN})_{6}\right), 0.3 \%$ Triton $\mathrm{X}-100$, and $0.27 \% \mathrm{X}$-gal. Following staining the embryos were washed in PBS, $0.3 \%$ Triton $\mathrm{X}-100$.

Third instar larvae were cut along the dorsal midline and pinned to a Sylgard (Dow Corning) dish in a solution of PBS. The larvae were rinsed once in PBS and fixed in PBS containing $1 \%$ glutaraldehyde for 15 min. Following fixation the larvae were rinsed three times in PBS and stained in the $\mathrm{Fe} / \mathrm{Na}$ Phosphate $\mathrm{X}$-gal staining solution described above without Triton X-100. After staining larvae were rinsed in PBS. Larval organs were then dissected and mounted in PBS containing $80 \%$ glycerol. Larval brains used for plastic sectioning were subsequently dehydrated through an ethanol series and prepared as in Tomlinson and Ready (1987) with the exception that osmium tetroxide treatment was omitted. One micrometer sections were cut on a RMC Ultramicrotome and then mounted in DPX for microscopy.

For $\beta$-galactosidase detection in adults, whole flies were embedded in OCT, frozen and $10 \mu \mathrm{m}$ sections were cut, heated to $50^{\circ} \mathrm{C}$, and stored at room temperature for at least $1 \mathrm{hr}$. Slides were then washed in three changes of PBS for 5 min per wash. The slides were dried and warmed to $37^{\circ} \mathrm{C} ; 100 \mu \mathrm{l}$ of prewarmed $\mathrm{Fe} / \mathrm{Na}$ Phosphate $\mathrm{X}$-gal $(0.33 \%)$ staining solution without Triton $\mathrm{X}-100$ was applied to each slide. Slides were then covered with a coverslip, incubated overnight at $37^{\circ} \mathrm{C}$ in a humidor and mounted in glycerol or dehydrated through an ethanol series and mounted in DPX (Mismer and Rubin, 1987).

In situ hybridization of sectioned tissue. ${ }^{35} \mathrm{~S}$ labeled sense and antisense RNA probes were transcribed (Maxiscript kit, Ambion) from a 267 base pair Pst I fragment (nucleotide positions 2606-2873; Atkinson et al., 1991) subcloned in Bluescript II KS vector (Stratagene). The probe was hydrolyzed to approximately 100 base pairs (Cox et al., 1984), ethanol precipitated, and resuspended in prehybridization solution (50\% formamide; $10 \%$ dextran sulfate; $10 \mathrm{mM}$ Tris, $\mathrm{pH} 7.5 ; 5 \mathrm{~mm}$ EDTA; $10 \mathrm{~mm}$ sodium phosphate buffer, $\mathrm{pH} 6.8 ; 1 \times$ Denhardt's; 10 mM DTT; $0.6 \mathrm{M} \mathrm{NaCl} ; 250 \mu \mathrm{g} / \mathrm{ml}$ polyadenylic acid; $250 \mu \mathrm{g} / \mathrm{ml}$ yeast tRNA; $250 \mu \mathrm{g} / \mathrm{ml}$ sheared denatured salmon sperm DNA) at a concen- tration of $0.5 \mathrm{ng} / \mu 1$. . The specific activity of all prohes was greater than $10^{8} \mathrm{cpm} / \mu \mathrm{g}$. Adult Canton $S$ and slo flies greater than $3 \mathrm{~d}$ old were embedded together in OCT medium and $8 \mu \mathrm{m}$ horizontal sections were cut. Slides were processed as described (Hafen and Levine, 1986) with the following exceptions: proteinase $\mathrm{K}$ was used at a concentration of $0.5 \mu \mathrm{g} / \mathrm{ml}$ rather than pronase; the $\mathrm{PBS} / \mathrm{glycine}$ wash was for $1 \mathrm{~min}$; after postfixing in paraformaldehyde the slides were washed in $1 \times$ PBS and then acetylated with $0.5 \%$ acetic anhydride in $0.1 \mathrm{M}$ triethanolamine/PBS for $10 \mathrm{~min}$, subsequently the slides were washed in PBS for $2 \mathrm{~min}$ and dehydrated in an ethanol series. Slides were prehybridized for $1-2 \mathrm{hr}$ at $50^{\circ} \mathrm{C}$ in a humidor under siliconized Corning coverslips Coverslips were removed by holding the slide upright and allowing the coverslip to slide off. Hybridization solution was applied and the coverslipped slides were incubated overnight at $50^{\circ} \mathrm{C}$ in a humid chamber.

Washes were performed as in Tsaur et al. (1992) with the following exceptions. RNase A $(20 \mu \mathrm{g} / \mathrm{ml})$ alone was used to reduce background. The $2 \times \mathrm{SSC}$ wash at $37^{\circ} \mathrm{C}$ was done with one change of buffer. The $0.1 \times \mathrm{SSC}$ wash was eliminated and in its place one $30 \mathrm{~min} 50^{\circ} \mathrm{C}$ wash in $0.3 \mathrm{M} \mathrm{NaCl} ; 0.1 \mathrm{M}$ Tris; $0.01 \mathrm{M}$ sodium phosphate, $5 \mathrm{mM}$ EDTA, pH $6.8,50 \%$ formamide; $14 \mathrm{~mm} \beta$-mercaptoethanol was performed. Slides were dehydrated in an ethanol series containing $0.3 \mathrm{M}$ ammonium acetate (Hafen and Levine, 1986). Autoradiography was performed as per Hafen and Levine using Kodak NTB2 emulsion. Exposure time was 12 weeks. In addition to the $s$ l $0^{4}$ negative control we also used the sense probes as a negative control. They were indistinguishable from the $s l^{4}$ negative control.

Embryo in situ hybridization. A population cage was established by allowing 24 bottles of flies to lay eggs in five coffee cans containing yeast molasses agar. When new flies appeared the cans were transferred to a new cage and flies were fed on fresh molasses agar supplemented with a yeast paste. The cage was maintained at $25^{\circ} \mathrm{C}$ and was kept humid with moist paper towcls. Food was changed twice daily. Embryo collections enriched for particular stages were made by placing a food plate in the cage for $1-6 \mathrm{hr}$, removing the plate, and allowing it to develop undisturbed to the desired stage. Embryo stages were confirmed by visual inspection (Campos-Ortega and Hartenstein, 1985; Wieschaus and Nüsslein-Volhard, 1986)

Whole-mount embryo in situ hybridization was performed essentially as described (Tautz and Pfeifle, 1989) with the following exceptions. Formaldehyde fixation was in $1 \times$ PBS, $50 \mathrm{~mm}$ EGTA, 10\% formaldehyde. Following the methanol treatment another two-step fixation was performed as follows. Embryos were washed in $5 \%$ formaldehyde in PBS for $20 \mathrm{~min}$ followed by a $20 \mathrm{~min}$ wash in $5 \%$ formaldehyde, $0.6 \%$ Triton X-100 in PBS. Hybridization of digoxygenin probes was performed in $50 \%$ deionized formamide, $5 \times \mathrm{SSC}, 100 \mu \mathrm{g} / \mathrm{ml} \mathrm{ssDNA}, 200$ $\mu \mathrm{g} / \mathrm{ml}$ tRNA, $0.1 \%$ Tween 20 .

Digoxigenin probes were prepared using the Genius protocol (Boehringer Mannheim). The probe was prepared from the $B g l \mathrm{II} / \mathrm{ClaI}$ restriction fragment from cDNA CH4 (Atkinson et al., 1991). This probe contains nearly all of the last exon of the slo gene and does not contain any known sites of alternative exon utilization. The negative control was homozygous slo ${ }^{4}$ embryos. In situ hybridization using the Shaker A1 cDNA (Schwarz et al., 1988) was performed in the same manner except that the entire cDNA was used as a probe.

\section{Results}

We wished to determine the tissue-specific expression pattern of slo throughout development. In situ hybridization and expression of a reporter gene were used to identify cells that express slo. The probes used for in situ hybridization were designed to recognize all slo mRNA splice variants. We have also used immunohistochemical staining to confirm the expression pattern and to examine the subcellular localization of the protein.

\section{Generation of anti-Slo antisera}

Polyclonal antibodies that recognize the slo CAK channel protein were raised in rabbits using a bacterial-expressed GST-slo fusion protein as the immunogen. As shown in Figure $1 B$, the carboxy-terminal 310 amino acid region of Slo found in the fusion protein is encoded by all slo splice products and therefore should identify all forms of the protein. The antisera raised 

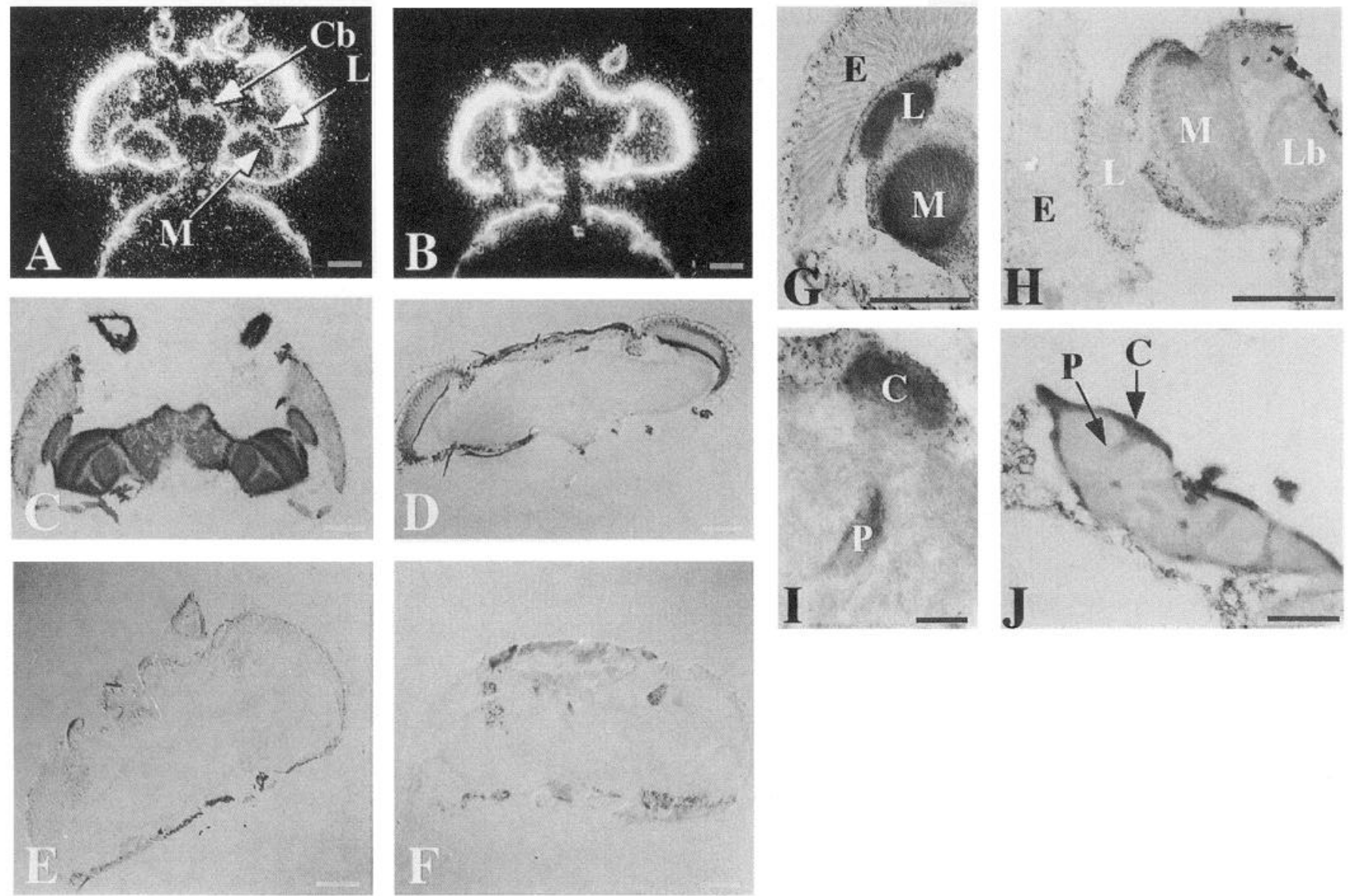

Figure 2. Expression of slo and slo-reporter in the adult head sections. $A$ and $B$ are ${ }^{35} \mathrm{~S}$ in situ hybridizations of sections with a slo cDNA fragment (see Fig. 1 and Materials and Methods for specific region). $A,{ }^{35} \mathrm{~S}$ in situ hybridization of a slo anti-sense probe to sections of wild type heads shows specific expression in the cortical regions of the optic lobes and central brain. Cuticle nonspecifically binds probe in this preparation. $B, s l{ }^{4}$ null mutant hybridized with the same probe shows only cuticular staining. Wild type hybridized with sense strand probes also show only cuticular staining. $C-G$ and $I$ show immunohistochemical staining of adult head with Ab1673. $C$, Ab1673 lightly stains neuronal cell bodies and strongly stains neuropil regions of the adult brain. Ab1673 stains the optic lobes (lamina, medulla, lobula, and lobula plate), central brain area, and antennae. The specificity of this antibody for the Slo protein is shown by the absence of immunoreactivity in the sections $D-F$. $D$, Mutant slo (null) head which does not express the slo gene. $E$, Wild type head stained with preimmune sera. $F$, Wild type head is not stained in the absence of primary antibody Ab1673. $G-J$ shows that the protein produced by the slo gene and the reporter gene show similar subcellular distribution in the adult brain. $G$, Optic lobes stained with Ab1673 showing that Slo protein is present in cortical regions but more strongly localizes to the neuropil. $H$, P1-9a optic lobes stained with anti- $\beta$-galactosidase antibody. The reporter protein is found in highest concentrations in the neuropil region and in lower amounts in the cortical regions. Staining can also be seen in the eye. I, Ab1673 staining of mushroom bodies. Slo protein is present in the mushroom body calyx and peduncle. $J$, Section showing mushroom body expression of the P1-9a fusion protein. Staining with anti- $\beta$-galactosidase antibody detects fusion protein in the calyx and peduncle. Labels: $E$, eye; $C b$, central brain; $C$, mushroom body calyx; $P$, mushroom body peduncle. The following letters are centered on the neuropil of the $L$, lamina; $L b$, lobula; $M$, medulla; and $P$, peduncle. The respective cortical regions surround the dark staining neuropil. Scale bars: $A-H$ and $J, 100 \mu \mathrm{m} ; I, 20 \mu \mathrm{m}$.

against the fusion protein is called Ab1673. Ab1673 specifically recognizes the Slo protein on sectioned tissue.

Specificity of the antibody is best demonstrated by comparing sections from wild type flies and from mutant $s \mathrm{O}^{4}$ flies (Fig. 2). The $s l o^{4}$ mutation is homozygous-viable $\gamma$ ray-induced null allele of the gene. This mutation completely eliminates the current conducted by the Slo channel (Atkinson et al., 1991). Furthermore, Northern blot analysis (Atkinson et al., 1991) and RNA/ PCR (data not shown) fail to detect the transcript in homozygous $s l o^{4}$ mutants. Therefore, $s l o^{4}$ mutant flies cannot contain any Slo protein for the Ab1673 to recognize. As shown in Figure 2, $C$ and $D$, the brain of a wild type adult fly stains strongly with Ab1673 but the $s l o^{4}$ mutant brain shows absolutely no staining.

Identification of the slo promoter

In Drosophila, electrophysiological and genetic studies have irrefutably demonstrated that the slo gene produces ion channels in some embryonic and larval body wall muscles and in the adult indirect flight muscles (Salkoff, 1983, 1985; Elkins et al., 1986; Gho and Mallart, 1986; Elkins and Ganetzky, 1988; Singh and Wu, 1989, 1990; Komatsu et al., 1990; Broadie and Bate, 1993). Nevertheless, neither in situ hybridization nor immunohistochemistry detected the presence of $s l o$ products in muscles (see Fig. 7A-D and data not shown). Similarly, molecular techniques have failed to detect Shaker (VAK channel) expression in muscles even though electrophysiological studies of the Shaker channel are typically performed in these cells (see Fig. $7 F$ and Tseng-Crank et al., 1991). It appears that $\mathrm{K}^{+}$channel transcripts and proteins are in vanishingly small abundance in muscle fibers, well below the sensitivity of in situ hybridization and antibody staining.

In order to detect low levels of expression we put a lacZ reporter gene into a slo exon so that the slo promoter could drive 
production of $\beta$-galactosidase. $\beta$-Galactosidase is extremely stable and can be colorimetrically detected in very small quantities. Furthermore, increased sensitivity can be achieved by constructing stocks with multiple insertions of the reporter gene.

To identify the slo promoter we used the 5'-most exon from cDNA 254 (Atkinson et al., 1991) as a probe to screen both a head-specific and an embryo-specific cDNA library. Twelve new cDNAs which included additional 5' sequences were isolated. All of these were mapped onto genomic DNA first by Southern blotting and then by sequencing portions of the cDNAs and genomic DNA. The alignment of the $5^{\prime}$ ends of the cDNAs is shown in Figure $1 A$. The $5^{\prime}$ ends of all cDNAs terminated at one of two discrete positions suggesting that two transcription start sites existed.

A $10 \mathrm{~kb}$ genomic DNA fragment, which included the first threc exons of slo and about $5 \mathrm{~kb}$ of DNA $5^{\prime}$ to the exon $\mathrm{Cl}$ (Fig. 1A), was subcloned into a modified pCaSperßgal Drosophila transformation vector (Thummel et al., 1988). The three exons in this fragment are $\mathrm{C} 1, \mathrm{C} 2$, and $\mathrm{C} 3$ (Tig. 1A). $\mathrm{C} 1$ and $\mathrm{C} 2$ are alternatively utilized $5^{\prime}$ most exons (data not shown). Fxon $C .1$ dnes not code for any aminn acids while exon C.2 includes a consensus translation start codon and codes for 17 AA. Some mRNAs from the endogenous gene begin with the $\mathrm{C} 1$ exon and others begin with $\mathrm{C} 2$. The $\mathrm{C} 3$ exon is common to all slo transcripts and also contains an in-frame ATG codon. In the transformation construct, P1-9, exon C3 of slo has been fuscd in frame with a lac $Z$ reporter gene. In $\mathrm{P} 1-9$, expression in the slo reading frame will direct the synthesis of $\beta$-galactosidase (Fig. 1A).

Construct P1-9 was transformed into Drosophila embryos, transformed stocks were established and assayed for expression of lacZ. P1-9 faithfully reproduces the slo neuronal expression pattern in the adult and embryo and it also enables us to visualize expression in muscle fibers. Three different P $1-9$ chromosome inscrtions werc assayed. All express $\beta$-galactosidase in the same pattern. Flies that carry three copies of the transformed gene were made by crossing flies with different insertion sites to one another. Multiple copies of the transformed gene do not alter its expression pattern but increase its expression level. Previously, expression of slo in muscle fibers has not been molecularly demonstrable.

\section{Expression in the adult brain}

In situ hybridization of a slo probe to sections of Drosophila heads showed that slo gene expression is widespread in the brain (Fig. 2A). More specifically, slo mRNA is found in the cortical regions of the lamina, medulla, lobula, and lobula plate of the visual system. However, the nonspecific binding of radiolabeled probe by cuticular structures makes it dificult to assay expression in the neurons of the eye.

Immunohistochemical staining with Ab1673 confirmed these results and showed more detail (Fig. $2 C, G, I$ ). In Drosophila, the cortical regions house the neuronal cell bodies and neuropil regions are composed of neuronal projections and synaptic connections, neuronal cell bodies are not found in this area (Bullock and Horridge, 1965; Strausfeld, 1976). Protein was clearly present in the cortex of all of the major regions of the brain (Fig. $2 C, G, I)$. However, the abundance of the protein was clearly many fold higher in the neuropil. Therefore, Slo CAK channel subunits exist not only in cell bodies but are also transported into neuronal projections, perhaps for use in synaptic boutons.

In the central brain a region of prominent staining is the mush- room bodies (Fig. 2I). These heavily studicd structures are centers of associative learning and have been shown to be involved in the establishment of memories in both flies and bees (Menzel et al., 1974; Han et al., 1992). The mushroom body calyx contains cell bodies and synaptic connections while the peduncle is thought to be composed only of neuropil, that is, to contain only axons and synaptic connections (Davis, 1993). The calyx and peduncle of the mushroom bodies stain with Ab1673 (Fig. 2I). The adult antennae are also clearly stained by Abl673 (Fig. 2C).

We also examined the expression of the slo reporter gene in the adult. Figure 2, $H$ and $J$, shows that the reporter reiterates the expression pattern defined by Ab1673 in the visual centers of the brain, the mushroom bodies and antennae. In fact, staining with anti- $\beta$-galactosidase antibody shows that this pattern is duplicated down to the level of transport of the protein down neuronal projections into the neuropil. This is particularly apparent in the peduncle of the mushroom bodies (Fig. 2J). Neuropil localization of the slo/ $\beta$-galactosidase fusion protein is far less efficient than the localization of authentic slo protein. Nevertheless, it would appear that the first three exons of slo contain sufficient information to guide the fusion protein dnwn neuronal projections. Figure $2 H$ also shows that the reporter directs expression of $\beta$-galactosidase in the adult eye. We believe that expression is in the photoreceptor cells. In summary, in the adult head, these three disparate approaches indicate that slo is expressed in the visual system including the eye, lamina, medulla, lobula and lobula plate, and in the mushroom bodies and antennae.

\section{Expression in adult muscle}

Figure 3 shows the reporter gene expression in thoracic, leg and head muscles. In all indirect flight muscles, $\beta$-galactosidase activity appears in a punctate and striated pattern. DAPI staining of nuclei indicates that the $\beta$-galactosidase activity coincides and surrounds nuclei (data not shown). Ilowever, in the direct flight muscles and in all other muscles (leg, abdomen, and head muscles) a uniform distribution of $\beta$-galactosidase is seen. This difference in localization was first apparent in pupae (Fig. 3A). In indirect flight muscle we believe that the fusion protein is enriched near the nucleus and endoplasmic reticulum.

\section{Expression in the pupa}

The development of ionic currents in flight muscle has been described in great detail (Salkoff, 1985). The current conducted by the slo CAK channel, $I_{\mathrm{CF}}$, does not appear until $24 \mathrm{hr}$ after the adult has left the pupal case. We were particularly interested in whether the appearance of $I_{\mathrm{C} F}$ was transcriptionally determined. As shown in Figure $3 A$, our reporter experiments show the promoter is active in the pupae in both indirect, direct Hight muscles, other striated muscles, the CNS and the PNS (antennae). Notice that the difference in the staining pattern between indirect and direct flight muscle exists in the pupae. This pattern is also seen in an adult fly five minutes following eclosion from the pupal case and furthermore, RNA/PCR experiments confirm that slo is expressed in pupae (data not shown).

\section{Expression in the larval muscle and brain}

Physiological and genetic assays have shown that slo is expressed in at least a subset of larval body wall muscles (Gho and Mallart, 1986; Singh and Wu, 1989, 1990; Komatsu et al., 1990). As expected, the Pl-9 reporter gene is expressed in all body wall muscles (Fig. 4A). The reporter gene also shows 

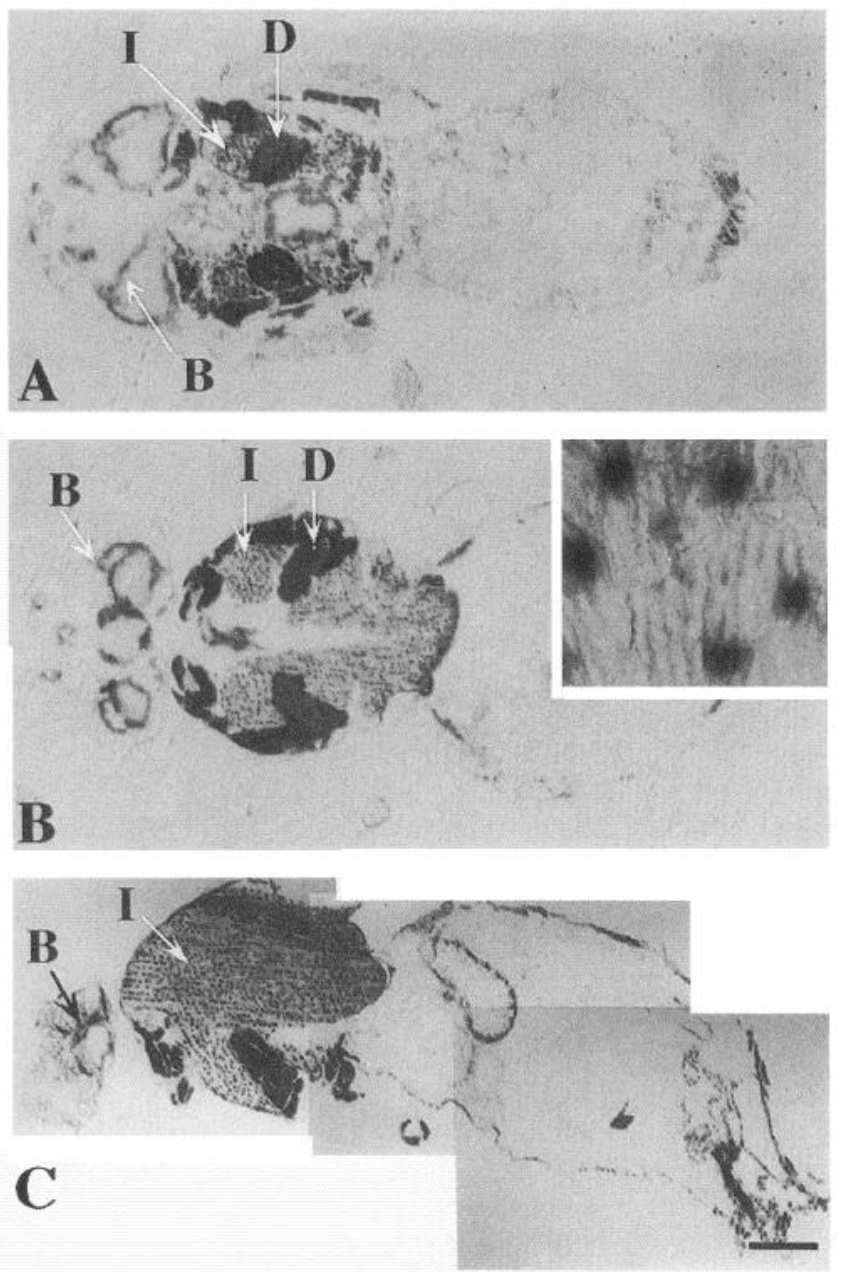

Figure 3. P1-9 transformants stained for $\beta$-galactosidase activity. Sections of both pupae and adults show expression in the brain, thoracic ganglion and indirect flight muscles and all other muscle types. A, Pupae, horizontal section. $B$, Adult, horizontal section. Inset shows punctiform staining specific to indirect flight muscle. $C$, Adult, sagittal section. Abbreviations: $B$, brain; $T$, thoracic ganglion; $I$, indirect flight muscle; $D$, direct flight muscle. Scale bar, $200 \mu \mathrm{m}$.

strong expression in the central brain and in cells surrounding the yentral nerve cord (Fig. $4 B$ ). Figure $4, E$ and $F$, shows that the cell membrane of neuronal cell bodies in the cortical regions of the larval brain stain in the enzymatic assay. The very clear delineation of the neuronal cell bodies in Figure $4, E$ and $F$ indicates that the first three exons of slo are capable of targeting the fusion protein to the cell membrane. The region of the larval brain called the optic lobes are undifferentiated precursors to the adult visual system (Truman et al., 1993). No expression of slo could be detected in these cells (Fig. 4B).

\section{Expression in larval tracheal cells and digestive system}

We have also seen expression of the reporter gene in the tracheal cells of the larvae (Fig. 5C). Furthermore, these cells also stain with Ab1673 demonstrating expression of the endogenous gene (Fig. 5A). The tracheal cells generate a branched tubular epithelial structure that serves as the respiratory organ of the animal.

The P1-9 reporter produces a very interesting pattern in the larval gut (Fig. 6A). The midgut has two positions of endogenous $\beta$-galactosidase activity. Transformants also show expression in three other regions, the esophagus, midgut, and the pos-
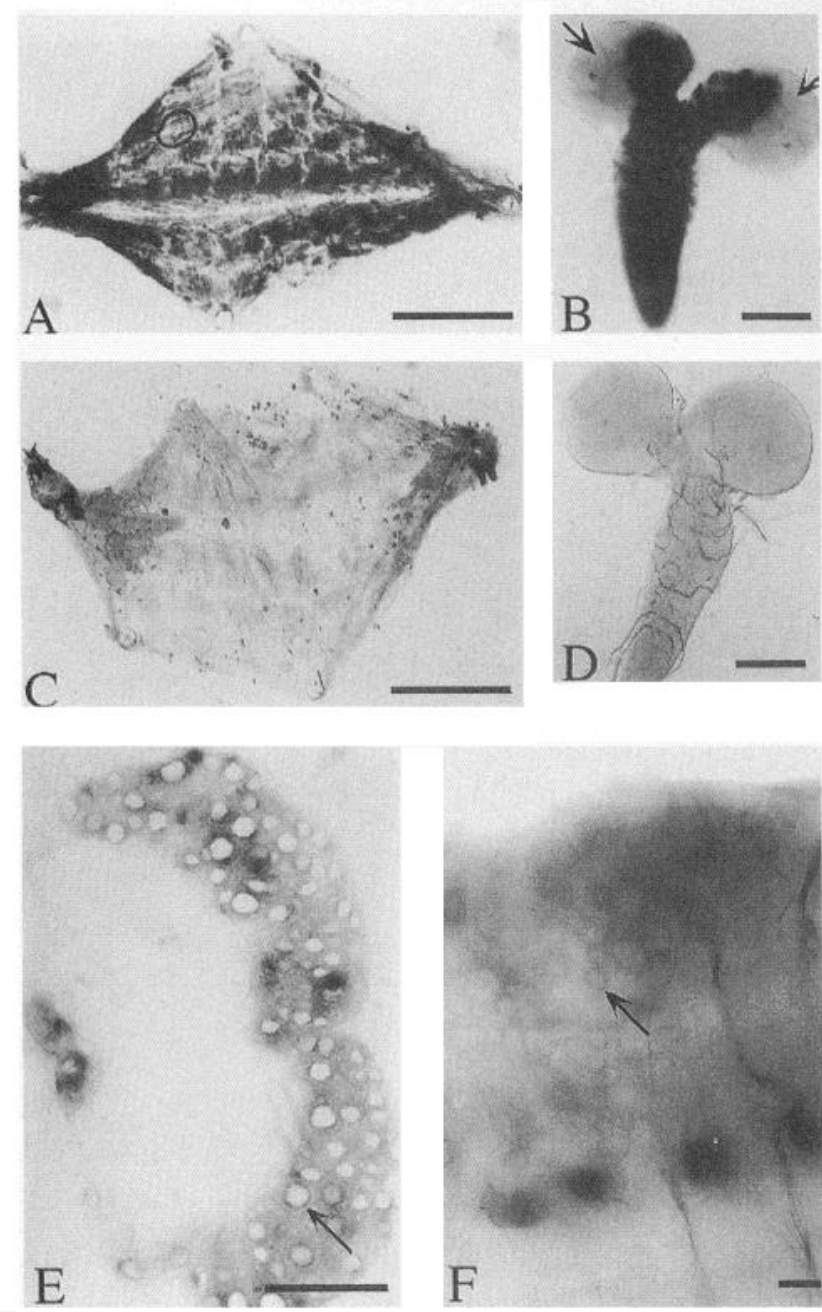

Figure 4. P1-9 reporter expression in larval muscles and brain. Third instar larvae fillets and brains were stained for $\beta$-galactosidase activity. $A, \mathrm{P} 1-9$ is expressed in all body wall muscles of the larvae. $B, \mathrm{P} 1-9$ expression in the larval brain. Arrows identify the immature optic lobes which do not express the reporter. $C$ and $D$, Untransformed controls. $E$, Cross-section of the ventral nerve cord of a P1-9 larval brain stained for $\beta$-galactosidase activity. $\beta$-Galactosidase activity localizes to the neuronal cell membrane (arrow). $F$, Ventral nerve cord (whole mount) of larval brain showing $\beta$-galactosidase localization to neuronal cell membranes (arrow). Scale bars: $A-D, 100 \mu \mathrm{m} ; E$ and $F, 10 \mu \mathrm{m}$.

terior end of the hindgut. The midgut expression roughly corresponds to the region seen in the embryonic midgut (see below), indicating that the expression pattern initiated during embryogenesis persists throughout larval life. We know of no muscles that are associated with the midgut at this position. The expression in the muscles associated with the larval esophagus and hindgut appear to be smooth muscle.

\section{Expression in the embryo}

In situ hybridization of slo probes to whole mount Drosophila embryos shows expression in the CNS, PNS, and in a spiral of cells surrounding just one loop in the developing midgut (Fig. $7 A-D)$. The expression pattern was documented with both a $3^{\prime}$ probe common to all of the identified slo transcripts (Fig. 1) and a nonoverlapping probe that contains the first 1144 nucleotides of slo cDNA z54 (data not shown). Both probes produced an identical hybridization pattern. This staining pattern is seen in 

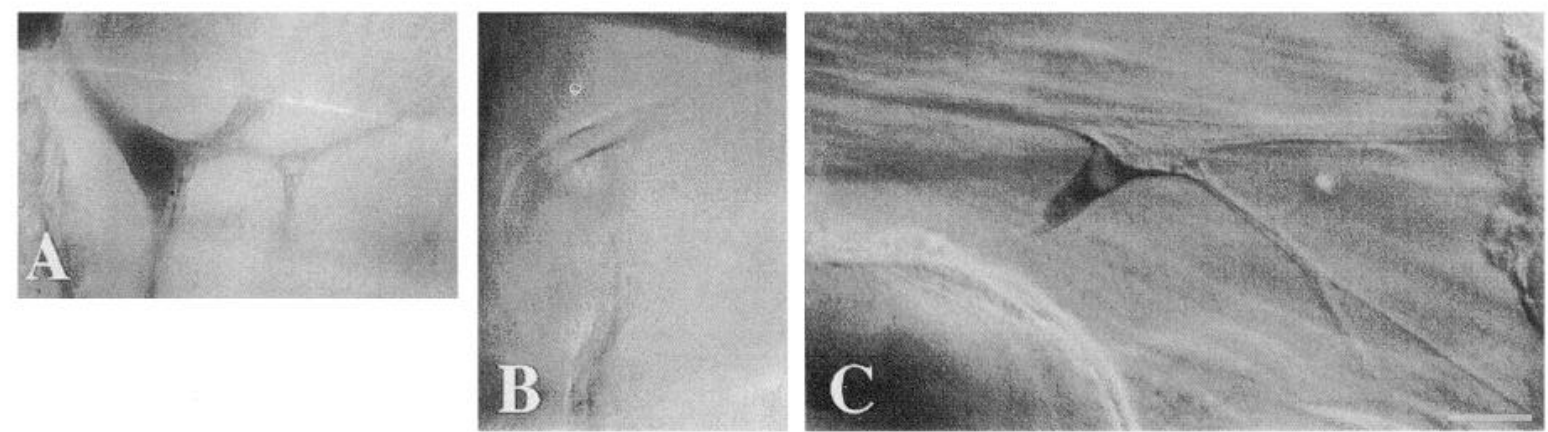

Figure 5. Expression in tracheal cells. A, Antisera Abl673 stains tracheal cells in the wild type larval body wall. $B$, The $s l \sigma^{4}$ mutation eliminates tracheal immunoreactivity. $C, \beta$-Galactosidase activity stain shows that the P1-9 reporter is also expressed in the tracheal cells. Scale bar, $10 \mu \mathrm{m}$.

wild type embryos (Fig. 7A-D) but not in flies homozygous for the $s l o^{4}$ null mutation (Fig. $7 E$ ). However, $s l o^{4}$ homozygotes do show expression of the Shaker (VAK channel) gene (Fig. $7 F$ ). Also seen in the embryo are a small number of slo-expressing cells in the midgut (Fig. 7D). Close examination reveals that these cells actually form a spiral around one loop of the midgut. These cells appear to be in the same region as those seen in the larval midgut.

In situ hybridization shows that expression first occurs at stage 14 of embryogenesis [11.5-13 hr after embryo laying (AEL)] in the subesophageal ganglion of the brain just at the time that condensation of the CNS is occurring (data not shown). By stage 15 (13-15 hr AEL) expression has spread to the entire CNS and PNS. By in situ hybridization the last cell type to show expression are cells of the body wall sensilla. It should be noted that, just as in the adult, expression cannot be detected in muscle by in situ hybridization.

The P1-9 slo reporter construct was also assayed for its em-
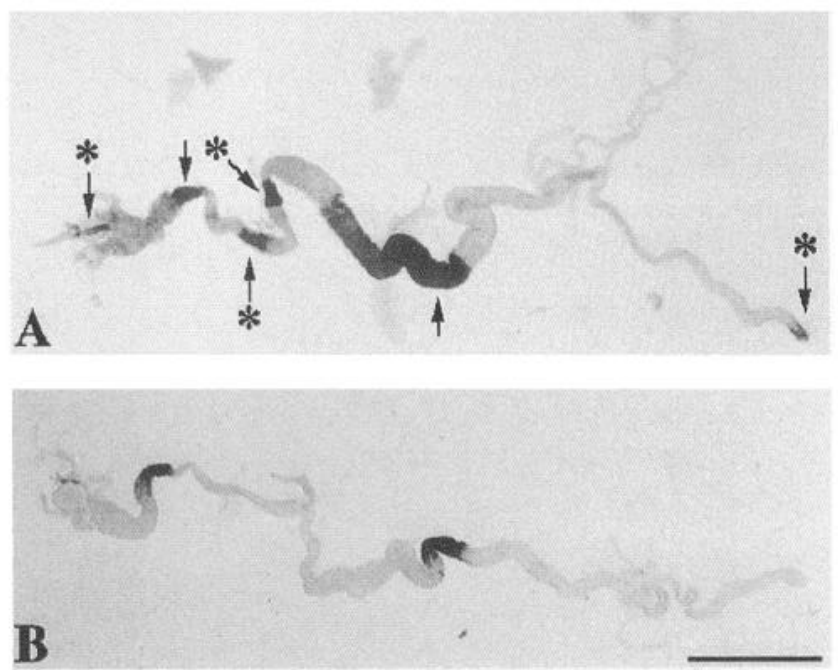

Figure 6. $\beta$-Galactosidase activity stain shows that the reporter is expressed in the larval digestive system. $A$, Larval digestive tract from a P1-9 transformant stained for $\beta$-galactosidase activity. There are six areas of $\beta$-galactosidase activity in this tissue. They are marked by arrowheads and asterisks identify activity only found in the P1-9 transformant. From left to right they are, P1-9 specific esophagus activity, endogenous midgut activity, two bands of P1-9 specific midgut activity, endogenous midgut activity and P1-9 specific hindgut activity. $B$, Untransformed digestive system shows endogenous midgut activity found in all larval digestive tracts. Scale bar, $1 \mathrm{~mm}$. bryonic expression pattern. P1-9 duplicates the temporal and tissue-specific pattern of expression of the endogenous slo gene in the CNS, PNS, and gut (Fig. 7G). Expression from P1-9 is first seen in the central brain area and then shortly later in the embryonic brain lobes, ventral nerve cord, antenno-maxillary complex, and midgut. Whereas we cannot molecularly demonstrate muscle expression from the endogenous gene; the P1-9 reporter appears to be expressed in all body wall muscle (Fig. 7G,H) with expression first appearing in developmental stage 13 (AEL $10.5-11.5$ ). In the CNS, expression is first detected early in stage 14. The reporter gene is also expressed in body wall sensilla, however, the reporter expression in the muscle makes them difficult to see. These neurons can be easily seen by in situ hybridization because muscles do not stain in this assay.

\section{Discussion}

We have described the developmental expression of the slo CAK channel gene in nerves, muscle, and epithelial derived cells. Initially, we chose in situ hybridization and an anti-slo antibody as our tools for this description. Using the $s l o^{4}$ null mutation as a negative control allowed us to unambiguously ascertain that our in situ hybridization and immunohistochemical staining were highly specific for products from the gene. Previously, it has been shown that the $s l l^{4}$ mutation fails to complement other slo mutations and that flight muscle of homozygous $s^{4}{ }^{4}$ lines does not express $I_{\mathrm{CF}}$. Furthermore, Northern blots and RNA/PCR do not detect slo transcripts in whole flies.

Using these techniques we detected expression in neural and epithelial-derived cells. However, we did not detect expression in muscle fibers, even fibers in which the presence CAK channels produced by the slo gene has been clearly demonstrated by whole cell voltage-clamp and patch-clamp analysis (Salkoff, 1983, 1985; Elkins et al., 1986; Gho and Mallart, 1986; Elkins and Ganetzky, 1988; Singh and Wu, 1989, 1990; Komatsu et al., 1990; Broadie and Bate, 1993). Inability to detect endogenous slo gene expression in muscle fibers suggests that its products are of very low abundance, far below the abundance in neural tissue. The failure of the antibody to visibly stain muscle fibers could also result from a protein modification which prevents antibody recognition. To circumvent this problem we cloned the slo promoter and used it to direct expression of $\beta$-galactosidase, a stable protein for which a variety of assays exist. In transformed flies this reporter provided an alternate means to determine where and when slo expression occurs during development.

In $s l o^{4}$ homozygotes, both the in situ hybridization pattern and 

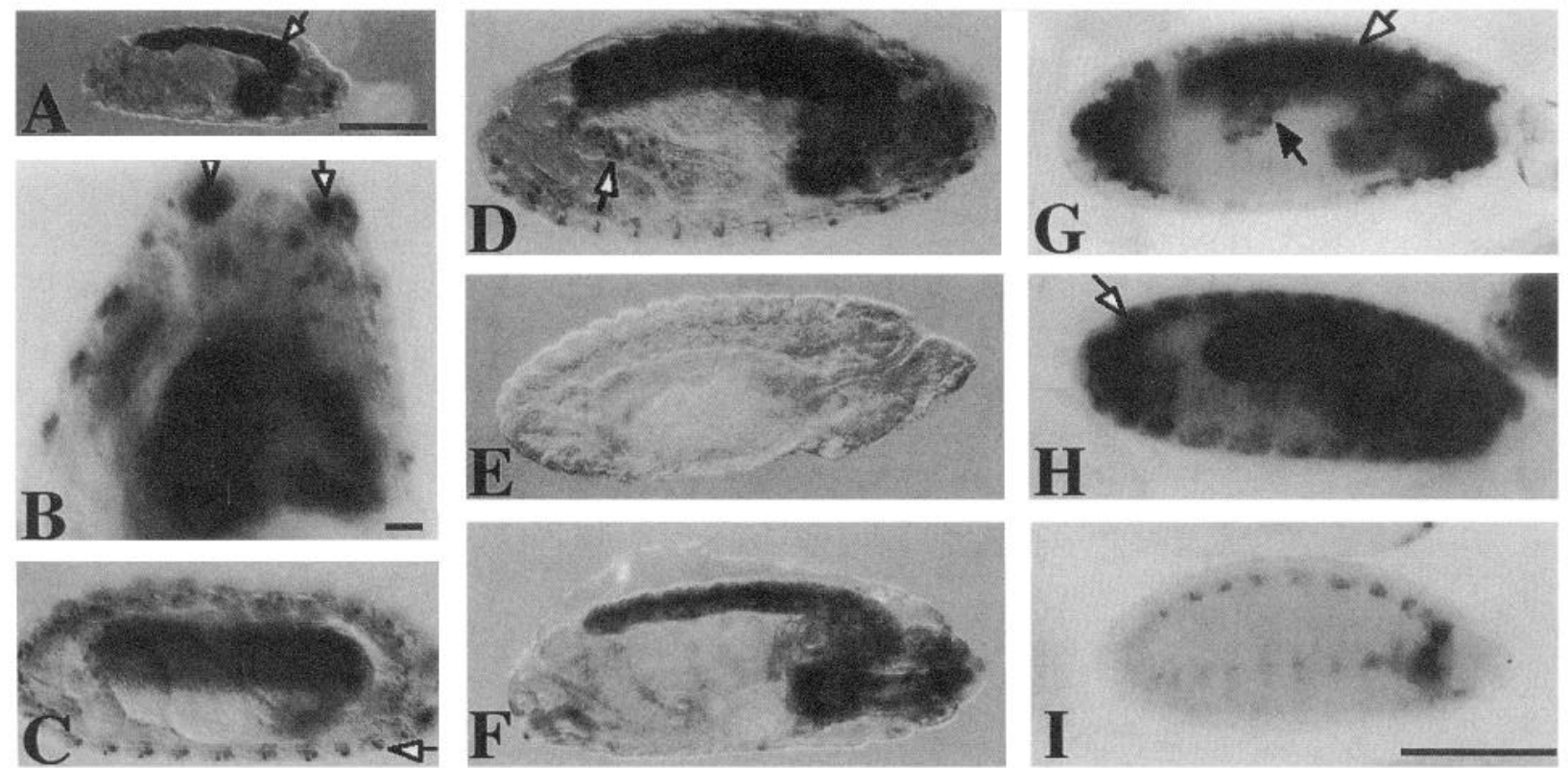

Figure 7. Expression of slo in embryos. A-E are whole mount in situ hybridization of slo cDNA probes to stage 15 embryos. Arrows identify specific structures. Different optical sections showing slo expression in the CNS, scale bar, $100 \mu \mathrm{m}(A)$; antenno-maxillary complex, scale bar, 10 $\mu \mathrm{m}(B)$; PNS $(C)$; and cells associated with one loop of the midgut $(D)$; slo mutant embryos do not hybridize to the probe $(E)$; but do hybridize to a Shaker A1 cDNA probe $(F)$. $G, \beta$-Galactosidase activity stain of P1-9 embryos shows that the reporter is expressed in the CNS (white arrow), antenno-maxillary complex, and midgut (black arrow) $(H)$ P1-9 embryo (different focal plane) clearly showing muscle expression of the reporter (arrow). $I$, Early stage 13 P1-9 embryo showing only muscle expression. Scale bar in $I$ equals $100 \mu \mathrm{m}$ and applies to $C-I$.

Ab1673 immunohistochemical staining of neural tissue are completely eliminated. Ab1673, however, still shows residual staining in the eyes of $s l o^{4}$ adults. Drosophila eyes are primarily neural tissue and this lack of specificity was unexpected and is unexplained. It may mean that photoreceptor neurons express a closely related cross-reacting $\mathrm{K}^{+}$channel. Due to this lack of specificity, Ab1673 immunohistochemistry does not provide any information concerning slo expression in the eyes.

In adults, slo mRNA is found in the cortex of the brain. Furthermore, antibody staining shows that the protein, while present in the cortex, most strongly localizes to neuropil. In flies, neuronal cell bodies are in the cortical regions while neuropil consists of neuronal projections and synaptic connections. Ab1673 also recognizes the mushroom bodies which are centers of associative learning in the fly. Both the mushroom body calyx and peduncle stain. The peduncle is thought to contain only axons and synaptic connections (Davis, 1993). It appears that the protein is transported down these axons and functions either in the axons or synaptic boutons. In frogs, CAK channels have been localized to synaptic boutons and are thought to be involved in modulating calcium influx (Robitaille et al., 1993).

In embryos, in situ hybridization shows that expression of the endogenous gene begins at early stage 14 in the subesophageal ganglion and then rapidly spreads to the developing brain lobes, ventral nerve cord, antenno-maxillary complex and the body wall PNS. Unexpectedly, by stage 15 expression can also be seen in a small number of cells that appear to form a spiral around one loop of the midgut. Even though Broadie and Bate (1993) have shown that slo is expressed in embryonic muscles, our in situ hybridization fails to detect muscle transcripts. We surmise that the mRNA must be of extremely low abundance.

The slo reporter gene reproduces the expression pattern of the endogenous gene in embryonic CNS, antenno-maxillary complex, and gut both with regard to tissue type and developmental onset of expression. Similarly, in adult heads the reporter duplicates the slo expression pattern. It appears then, that the $10 \mathrm{~kb}$ of genomic DNA included in the reporter contains the slo transcriptional control region.

There are two caveats to this recapitulation of the endogenous gene's expression pattern. In adult eyes we are unable to document endogenous gene expression because (1) the cuticle binds in situ hybridization probes and (2) the loss of antibody specificity within the eye. In addition, neither in situ hybridization nor immunohistochemical staining detected endogenous gene expression in muscle of any developmental stage. Therefore, the conclusion that slo is expressed in both the eye and widely in muscle is based solely on data collected using the reporter gene.

It is interesting that during muscle development, expression of the reporter precedes the appearance of the $I_{\mathrm{CF}}$ by many hours. In embryonic muscle, the reporter is expressed at about stage 13 while the current, $I_{\mathrm{CF}}$, first appears at stage 17 (Broadie and Bate, 1993), a difference of some $6 \mathrm{hr}$. Similarly, $I_{\mathrm{CF}}$ is not found in pupal flight muscle and only appears in adults approximately $24 \mathrm{hr}$ post-eclosion; however, reporter expression is apparent throughout pupariation and in the adult $5 \mathrm{~min}$ post-eclosion. It appears that a post-transcriptional mechanism may exist which prevents premature assembly or operation of slo channels. In pupal flight muscle precedent exists for such an event. Wei and Salkoff (1986) have shown that $\mathrm{Ca}^{2+}$ channels are present as early as $72 \mathrm{hr}$ pupariation but that they are inactive until eclosion. This appears to result from inactivation by intracellular $\mathrm{Ca}^{2+}$.

While examining reporter expression in the larval body wall we noticed that tracheal cells strongly stained for $\beta$-galactosidase activity. Staining larval fillets with Ab1673 showed that these cells also express the endogenous gene. Tracheal cells are modified epithelia that produce and maintain the insect respiratory system. These cells are functionally similar to vertebrate 
lung epithelia (Manning and Krasnow, 1993). Throughout development they transport fluid out of the tracheae to clear these air passageways. Electrolyte transport in vertebrate lung epithelia involves the flux of $\mathrm{Cl}^{-}, \mathrm{Na}^{+}$and $\mathrm{K}^{+}$ions through channels across the cell membrane (McCann and Welsh, 1990). The slo CAK channels may be participating in this process in tracheal cells.

In larvae the reporter is also expressed in a region of the larval midgut. These appear to be the same cells which express endogenous slo during embryogenesis. We are unaware of any muscles or neurons that contact the midgut at these positions. Although we have not been able to unambiguously identify these cells, these cells may be homologous to vertebrate colonocytes. In vertebrates colonocytes, CAK channels have a well documented role in water movement and $\mathrm{Na}^{+}$coupled amino acid absorbtion (Sheppard et al., 1988; Turnheim et al., 1989).

The reporter gene includes the first threc slo exons, the third of which is truncated and in-frame with the lacZ gene. The third exon, C.3, includes the first putative transmembrane domain (S1) of slo (Atkinson et al., 1991). Therefore, the fusion protein should be targeted to the cytoplasmic membrane and the $\beta$-galactosidase moiety should be tethered to the outside of the cell. Indeed, close inspection of stained larval brains show that $\beta$-galactosidase activity delimits cell bodies. In adult brains, Slo protein and the reporter protein localizes to neuropil in the optic lobes and mushroom bodies. It appears that the first three exons of slo contain information which directs the protein into cell membranes and down neuronal projections in at least some neurons. We have not yet identified the responsible targeting signal.

Until recently, tissue-specific expression of CAK channels has been ascertained primarily by electrophysiology. We have been able to document, in the whole organism, the developmental expression of a CAK channel gene. Interestingly, the catalog of slo-expressing tissues closely parallels a list of vertebrate tissues in which C.AK channels have been identified. In vertebrates, CAK channels have been detected in nervous tissue, striated and smooth muscle, intestinal colonocytes, and lung epithelia. Similarly, the slo gene is expressed in CNS, PNS, both smooth and striated muscle, midgut, and tracheal cells.

It is remarkable that a single channel gene is expressed in a broad range of functionally different tissues where the channels are likely to be physiologically distinct. It is unlikely that in all these tissues the slo-derived channels are biophysically identical. One of the most striking features of the slo gene is that its mRNAs are subject to extensive alternative splicing. Alternative splicing provides a mechanism whereby the gene is free to produce channels tailored for operation in particular tissues. We anticipate that tissue-specific splicing of slo transcripts will prove to be the major means of producing channels custommade for individual tissues. This work will provide a foundation from which the regulation of CAK chamel gene expression can be studied.

\section{References}

Adclman JP, Shen KZ, Kavanaugh MP, Warren RA, Wu YN, Lagrutta A, Bond CT, North RA (1992) Calcium-activated potassium channels expressed from cloned complementary DNAs. Neuron 9:209216.

Atkinson NS, Robertson GA, Ganetzky B (1991) A component of calcium-activated potassium channels encoded by the Drosophila slo locus. Science 253:551-555.

Broadie KS, Bate M (1993) Development of larval muscle properties in the embryonic myotubes of Drosophila melanogaster. J Neurosci $13: 167-180$

Bullock TH, Horridge GA (1965) Structure and function in the nervous systems of invertebrates, p 52. San Francisco: Freeman.

Butler A, Tsunoda S, McCobb DP, Wei A. Salkoff L (1993) mSlo, a complex mouse gene encoding "maxi" calcium-activated potassium channels. Science 261:221-224.

Campos-Ortega JA, Hartenstein V (1985) The embryonic development of Drosophila melanogaster. Berlin: Springer.

Cox KH, DeLeon DV, Angerer LM, Angerer RC (1984) Detection of mRNAs in sea urchin embryos by in situ hybridization using asymmetric RNA probes. Dev Biol 101:485-502.

Davis RL (1993) Mushroom bodies and Drosophila learning. Neuron 11:1-14.

Flkins T, Ganetzky B (1988) The roles of potassium currents in $\mathrm{Dro}$ sophila flight muscles. J Neurosci 8:428-434.

Elkins T, Ganetzky B, Wu C-F (1986) A Drosophila mutation that climinates a calcium-dependent potassium current. Proc Natl Acad Sci USA 83:8415-8419.

Gho M, Mallart A (1986) Two distinct calcium-activated potassium currents in larval muscle fibres of Drosophila melanogaster. Pfiuegers Arch 407:526-533.

Hafen E, Levine M (1986) The localization of RNAs in Drosophila tissue sections by in situ hybridization. In: Drosophila: a practical approach (Roberts DB, ed) pp 139-157. Oxford: IRL.

Hamilton BA, Palazzolo MJ, Meyerowitz EM (1991) Rapid isolation of long cDNA clones from existing libraries. Nucleic Acids Res 19: $1951-1952$

Han PL, Levin LR, Reed RR, Davis RL (1992) Preferential expression of the Drosonbila rutahaga gens in mushroom bodies, neural senters for learning in insects. Neuron 9:619-627.

Hoyle G (1983) Muscles and their neural control. New York: Wiley.

Klambt C, Jacobs JR, Goodman CS (1991) The midline of Drosophila nervous system: a model for the genetic analysis of cell fate, cell migration, and growth cone guidance. Cell 64:801-815.

Knaus HG, Garcia-Calvo M, Kaczorowski GJ, Garcia ML (1994) Subunit composition of the high conductance calcium-activated potassium channel from smooth muscle, a representative of the mSlo and slowpoke family of potassium channels. J Biol Chem 269:39213924.

Komatsu A, Singh S, Rathe P, Wu C-F (1990) Mutational and gene dosage analysis of calcium-activated potassium channels in Drosophila: correlation of micro- and macroscopic currents. Neuron 4:313 321

Manning G, Krasnow MA (1993) Development of the Drosophila tracheal system. In: The development of Drosophila melanogaster (Bate M, Martinez-Arias A, eds), pp 609-685. Cold Spring Harbor, NY: Cold Spring Harbor Laboratory.

McCann JD, Welsh MJ (1990) Regulation of $\mathrm{Cl}^{-}$and $\mathrm{K}^{+}$channels in airway epithelium. Annu Rev Physiol 52:115-135.

Menzel R, Erber J, Masuhr T (1974) Learning and memory in the honeybee. In: Experimental analysis of insect behavior (BartonBrowne L, ed), pp 195-217. Berlin: Springer.

Mismer D, Rubin GM (1987) Analysis of the promoter of the ninaE opsin gene in Drosophila melanogaster. Genetics 116:565-578.

Robertson HM, Preston CR, Phillis RW, Johnson-Schlitz DM, Benz WK, Engels WR (1988) A stable genomic source of P-element transposase in Drosophila melanogaster. Genetics 118:461-470.

Robitaille R, Garcia ML, Kaczorowski GJ, Charlton MP (1993) Functional colocalization of calcium and calcium-gated potassium channels in control of transmitter release. Neuron 11:645-655.

Salkoff L (1983) Drosophila mutants reveal two components of fast outward current. Nature 302:249-251.

Salkoff L (1985) Development of ion channels in the flight muscles of Drosophila. J Physiol (Paris) 80:275-282.

Salkoff LB, Wyman RJ (1983) Ion currents in Drosophila flight muscles. J Physiol (Lond) 337:687-709

Sambrook J, Fritsch EF, Maniatis T (1989) Molecular cloning: a laboratory manual. Cold Spring Harbor, NY: Cold Spring Harbor Laboratory.

Schwarz TL, Tempel BL, Papazian DM, Jan YN, Jan LY (1988) Multiple potassium-channel components are produced by alternative splicing at the Shaker locus in Drosophila. Nature 331:137-142.

Schwarz TL, Papazian DM, Carretto RC, Jan YN, Jan LY (1990) Immunological characterization of $\mathrm{K}^{+}$channel components from the 
Shaker locus and differential distribution of splicing variants in Drosophila. Neuron 2:119-127.

Sheppard DN, Giraldez F, Sepúlveda FV (1988) Kinetics of voltageand $\mathrm{Ca}^{2+}$ activation and $\mathrm{Ba}^{2+}$ blockade of a large-conductance $\mathrm{K}^{+}$ channel from Necturus enterocytes. J Membr Biol 105:65-75.

Singh S, Wu C-F (1989) Complete separation of four potassium currents in Drosophila. Neuron 2:1325-1329.

Singh S, Wu C-F (1990) Properties of potassium currents and their role in membrane excitability in Drosophila larval muscle fibers. J Exp Biol 152:59-76.

Smith DB, Johnson KS (1988) Single-step purification of polypeptides expressed in Escherichia coli as fusions with glutathione S-transferase. Gene 67:31-40.

Spradling AC (1986) P-Element mediated transformation. In Drosophila: a practical approach (Roberts DB, ed), pp 175-196. Oxford: IRL. Strausfeld NJ (1976) Atlas of an insect brain, p 19. Berlin: Springer.

Tautz D, Pfeifle C (1989) A non-radioactive in situ hybridization method for the localization of specific RNAs in Drosophila embryos reveals translational control of the segmentation gene hunchback. Chromosoma 98:81-85.

Thummel CS, Boulet AM, Lipshitz HD (1988) Vectors for Drosophila
P-element-mediated tranformation and tissue culture transfection. Gene 74:445-456.

Tomlinson A, Ready DF (1987) Cell fate in the Drosophila ommatidium. Dev Biol 123:264 275.

Truman JW, Taylor BJ, Awad TA (1993) Formation of the adult nervous system. In: The development of Drosophila melanogaster (Bate M, Martinez-Arias A, eds), pp 1245-1275. Cold Spring IIarbor, NY: Cold Spring Harbor Laboratory.

Tsaur ML, Sheng M, Lowenstein DH, Jan YN, Jan LY (1992) Differential expression of $\mathrm{K}^{+}$channel mRNAs in the rat brain and downregulation in the hippocampus following seizures. Neuron 8:10551057.

Tseng-Crank J, Pollock JA, Hayashi I, Tanouye MA (1991) Expression of ion channel genes in Drosophila. J Neurogenet 7:229-239.

Turnheim K, Constantin J, Chan S, Schultz SG (1989) Reconstitution of a calcium-activated potassium channel in basolateral membranes of rabbit colonocytes into lipid bilayers. J Membr Biol 112:247-254.

Wei A Salkoff L (1986) Occult Drosophila calcium channels and twinning of calcium and voltage-activated potassium channels. Science 233:780-782.

Wieschaus E, Nüsslein-Volhard C (1986) Looking at embryos. In: Drosophila: a practical approach (Roberts DB, ed), pp 199-227. Oxford: IRL. 